\title{
Terpenes in the Aroma of Grapes and Wines: A Review
}

\section{J. MARAIS}

Viticultural and Oenological Research Institute, Private Bag X5026,

7600 Stellenbosch, Republic of South Africa.

The author would like to express his thanks and appreciation to Dr. P. J. Williams of the Australian Wine Research Institute, Glen Osmond, South Australia for critically reading the manuscript.

Submitted for publication: August 1983

Accepted for publication: October 1983

\begin{abstract}
This paper reviews some aspects of terpenes and terpene derivatives in grapes and wines, such as the identification of these compounds, their use in the identification of and differentiation between cultivars, the effect of grape maturity and wine-making techniques on terpene concentrations and wine quality, as well as transformations of terpenes in grapes and wine.
\end{abstract}

Wine quality is determined by a complex balance of all the wine aroma components as perceived by sensory evaluation. Although several sensory parameters may play a role in the acceptance and enjoyment of wine, the flavour of wine is possibly the most important factor. Flavour is the result of the interaction between certain chemical compounds in wine and the senses of smell and taste of the consumer. Approximately 550 volatile components have been identified in grapes and wine, and many of these components contribute to the aroma (Schreier, 1979). A large number of components appear in micro concentrations in wine, and in many cases these have the most significant effect on wine quality. With respect to their origin, wine aroma components may be classified into four groups (Schreier, 1979).

- Originating from the grapes.

- Produced during the crushing of the grapes by the action of certain enzymes.

- Produced during fermentation.

- Produced during maturation of wine.

A typical cultivar bouquet in wine can be attributed to the bouquet of the corresponding grape cultivar and is caused by:

- Compounds typical of the grape cultivar which are transferred from the grape to the wine without being affected by the fermentation process.

- Compounds equally typical of the grape cultivar which are formed from a precursor(s) during fermentation (Condonnier \& Bayonove, 1978).

\section{GENERAL}

The wine aroma components responsible for the characteristic aroma of muscat and aroma related wines, are mainly derived from the grape and are known as terpene compounds. True muscat cultivars include Muscat d'Alexandrie, Morio Muscat, and Muscat blanc, whereas aroma related cultivars include Weisser Riesling, Bukettraube, Gewürztraminer, Ferńao Pires and Scheurebe. Terpene compounds may also contribute to the aromas of other non-muscat cultivars. Nearly 50 terpene compounds in grapes and wine are known at this stage, of which 46 were identified in grapes and 30 in wines (Table 1). They include only monoterpenes and sesquiterpenes.
A number of prominent aroma components of grapes and wine, which are of terpenic origin, are also of great importance: Some are listed in Table 2.

The most prominent terpene compounds occurring generally and in high concentrations in muscat and aroma related grapes and wines are linalool, geraniol, nerol, $\propto$-terpineol and hotrienol. Of equal importance is the great number of terpene compounds which occur in micro concentrations but which have significant effects on aroma. Different complex combinations of terpene compounds are responsible for the characteristic aromas of different muscat and aroma related cultivars. These subtle differences in terpene profiles may also occur within the same cultivar originating from different areas. Typical aroma descriptions of some important terpenes are floral, rose-like (geraniol, nerol, rose oxides), coriander (linalool), camphoraceous (linalool oxides), green (nerol oxide) and herbaceous (Meilgaard, 1975; Simpson, 1979 b).

Several studies have been undertaken regarding the chemistry of terpenes, their synthesis, systematic classifications, etc. (Pinder, 1960; Klouwen \& Ter Heide, 1962; Ter Heide, 1968; Ter Heide, 1976). Devon \& Scott (1972) presented a classification of 4000 components of terpenic nature. Of these components, 400 are monoterpenes and 1000 sesquiterpenes. Monoterpenes and sesquiterpenes are characteristic components of the essential oils produced by plants. Monoterpenes $\left(C_{10}\right)$ and sesquiterpenes $\left(C_{15}\right)$ are the lower molecular weight representatives of the terpenoid components and comprise two and three isoprene units, respectively. A general representation of the biosynthesis of monoterpenes and sesquiterpenes, as well as some enzymatic transformations such as oxidation, reduction and dehydration, has been summarised by Croteau (1975).

Terpene concentrations in grapes and wine would obviously depend on various factors, such as cultivar, region and wine-making techniques. Since the majority of the terpene compounds occur in micro concentrations in grapes and wines, their quantification is quite difficult. Consequently, their concentrations are normally expressed as relative amounts. Examples of absolute terpene concentrations in muscat and aroma related grapes and wines, as well as some aroma threshold values, are shown in Table 3 . 
TABLE 1

Monoterpenes and sesquiterpenes in grapes and wines.
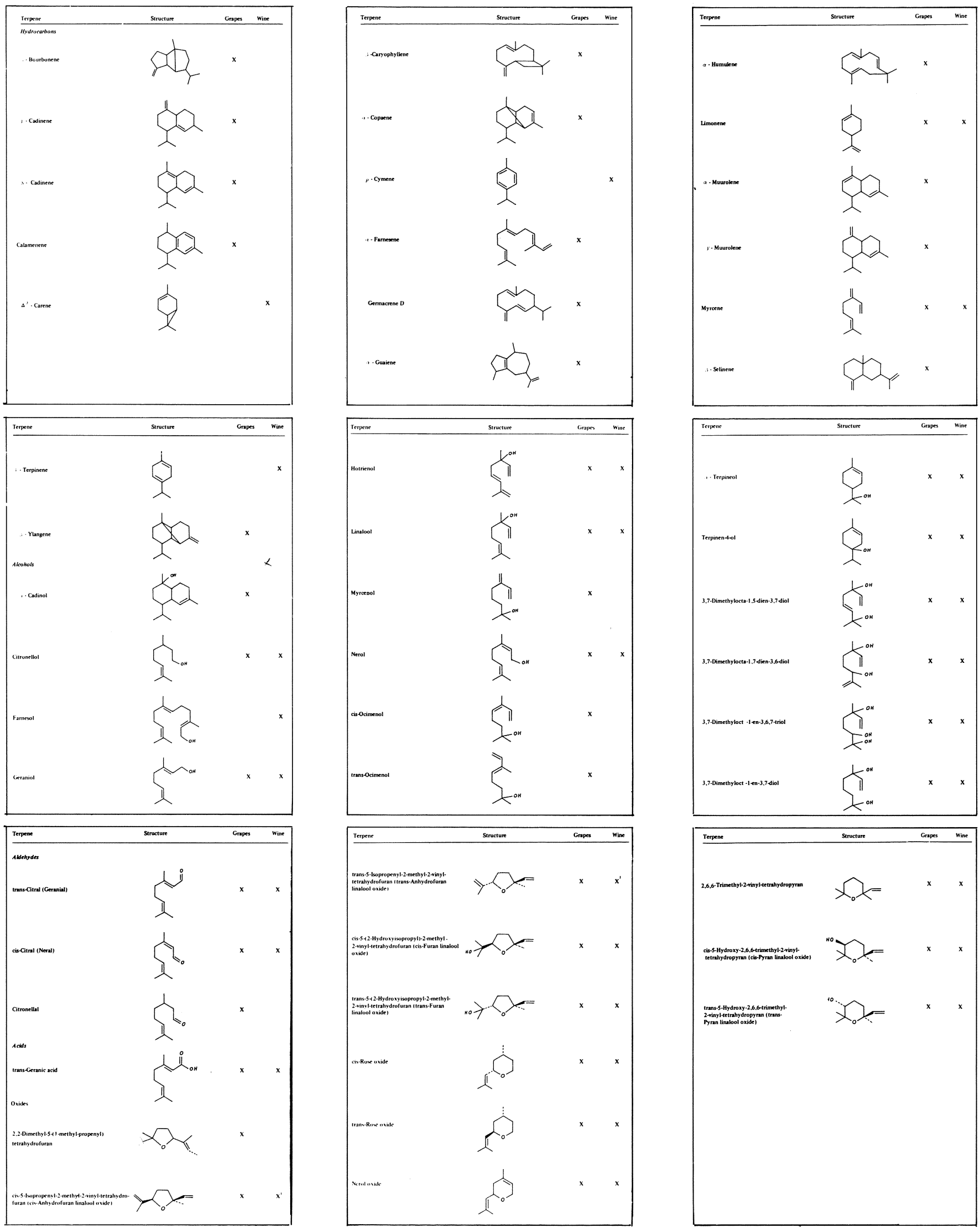

References to these terpenes are available in Supplements 5 (1980, wine) and 6 (1981, grape) to the Fourth Edition of "Volatile Compounds in Food"' (Van Straten, De Beauveser \& Visscher, 1977), except for:

$\mathrm{X}^{1}$ Rapp \& Knipser, 1980.

$\mathrm{X}$ indicates presence in either grapes or wines. 
TABLE 2

Some terpene derivatives in grapes and wines.

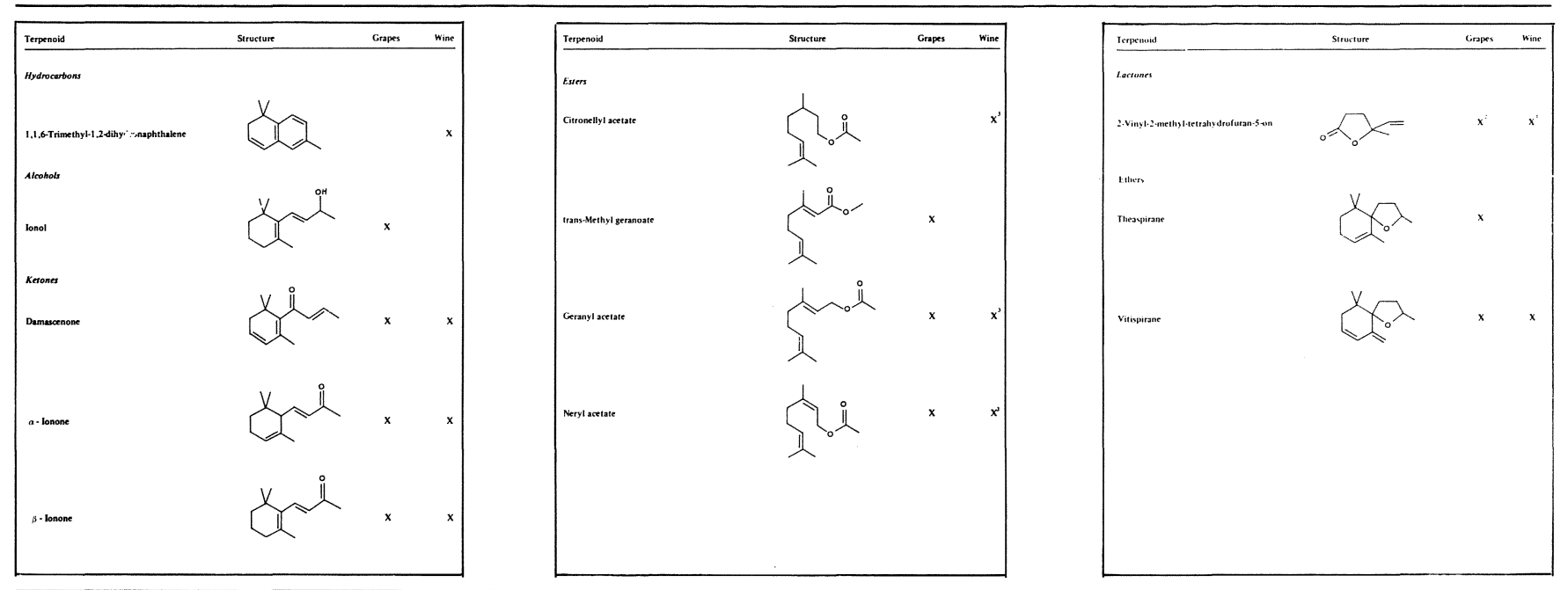

References to these terpene derivatives are available in Supplements 5 (1980, wine) and 6 (1981, grape) to the Fourth Edition of "Volatile Compounds in Food" (Van Straten, De Beauveser \& Visscher, 1977), except for: $\mathrm{X}^{1}$ Schreier \& Drawert, 1974 b.

$\mathrm{X}^{2}$ Schreier, Drawert \& Junker, 1976 b.

$\mathrm{X}^{3}$ Rapp \& Knipser, 1980.

$\mathrm{X}$ indicates presence in either grapes or wines.

Identification and role of terpene compounds in grapes, wine and grape leaves: Considerable research has been done in respect of the identification and contribution of terpene compounds to the muscat aroma of muscat grapes and wines. Austerweil (1946) was the first to suggest that the aroma of muscat grapes can be ascribed to terpene compounds, especially linalool and its derivatives. Cordonnier (1956) investigated the aroma of muscat wines and tentatively identified linalool, geraniol, $\propto$-terpineol and limonene by means of thin layer chromatography.

Webb \& Kepner (1957), Stevens et al. (1966), Webb, Kepner \& Maggiora (1966) and Wenzel \& De Vries (1968) undertook further investigations and confirmed the definite contribution of linalool and geraniol to the overall aroma of muscat grapes. Research undertaken in this regard till approximately the end of the sixties, mainly concentrated on Muscat d'Alexandrie grapes and the effects of mainly linalool and geraniol on muscat aroma. Research workers differed in respect of the contribution of these terpenes to muscat aroma, and a clear relationship between the concentrations of these compounds and muscat aroma was not always demonstrable.

Technological development in gas chromatography and mass spectrometry accelerated identification of terpene compounds and the establishment of the effect of these compounds on the aroma of muscat and aroma related grapes and wines (Usseglio-Tomasset, 1966; Usseglio-Tomasset, Astegniano \& Matta, 1966; UsseglioTomasset, 1969; Prillinger \& Madner, 1970; Terrier \& Boidron, 1972 a,b; Terrier, Boidron \& Ribéreau-Gayon, 1972 a,b; Schreier \& Drawert, 1974 a,b; RibéreauGayon, Boidron \& Terrier, 1975; Bayonove, Richard \& Cordonnier, 1976; Schreier, Drawert \& Junker, 1977; Usseglio-Tomasset \& Di Stefano, 1979).

Recently several new terpene compounds have been identified in grape and wine aromas. In general, there are indications that more terpenes other than linalool and geraniol contribute to muscat and related aromas. Available literature since 1974 indicate that the following new terpenes had been identified. Schreier, Drawert \& Junker (1974) identified 3,7 - dimethylocta - 1,5,7 trien - 3 - ol (hotrienol) in grape and wine aromas of the cultivars Weisser Riesling, Gewürztraminer, Ruländer, Müller Thurgau, Scheurebe, Optima and Rieslaner. Rapp \& Knipser (1979) identified 3,7 - dimethyl - octa 1,5 - dien - 3,7 - diol in the grapes and wines of the cultivars Scheurebe, Weisser Riesling and Forta, while Rapp, Knipser \& Engel (1980) identified 3,7 dimethylocta - 1,7 - dien - 3,6 - diol in the grapes and wines of the cultivars Blauer Muskateller, Schönburger, Morio Muscat and Sieger. Williams, Strauss \& Wilson (1980a) identified 3,7 - dimethyloct - 1 - en - 3,6,7 - triol, 3,7 - dimethyloct - 1 - en - 3,7 - diol, 3,7 - dimethylocta 1,7 - dien - 3,6 - diol and 3,7 - dimethylocta - 1,5 - dien 3,7 - diol in the grapes and wines of Muscat d'Alexandrie. The same group (1980b) identified 2,6,6 - trimethyl - 2 - vinyltetrahydropyran, cis - and trans - 5 isopropenyl - 2 - methyl - 2 - vinyltetrahydrofuran, 2,2 dimethyl - 5 - (1 - methylpropenyl) tetrahydrofuran, myrcenol and cis - and trans - ocimenol in heated grape juice of muscat cultivars.

Terrier et al. (1972 b) and Ribéreau-Gayon et al. (1975) determined the aroma threshold values of some individual terpene compounds as well as terpene mixtures. The authors found linalool and geraniol to be the most important compounds because of the high concentrations in which they normally occur in muscat grapes and wines, as well as their low threshold values. It was found that terpenes interact to such an extent that one component can increase the aroma of another and that a mixture could become more aromatic than the most aromatic single component which belongs to that mixture. For example, the aroma threshold value of linalool was found to be $100 \mu \mathrm{g} / l$, while a mixture which 
TABLE 3

Aroma threshold values and concentrations* of some terpenes in muscat and aroma related grapes (G) and wines (W).

\begin{tabular}{|c|c|c|c|c|c|c|}
\hline \multirow[t]{2}{*}{ Terpene } & \multirow{2}{*}{$\begin{array}{l}\text { Aroma } \\
\text { threshold } \\
(\mu \mathrm{g} / l)\end{array}$} & \multirow[t]{2}{*}{ Reference } & \multirow{2}{*}{$\begin{array}{l}\text { Occur- } \\
\text { rence }\end{array}$} & \multicolumn{2}{|c|}{ Concentration $(\mu g / l)$} & \multirow[t]{2}{*}{ Reference } \\
\hline & & & & $\min$ & $\max$ & \\
\hline Citronellol & - & - & $\mathrm{W}$ & 1 & 5 & 7 \\
\hline \multirow[t]{5}{*}{ Geraniol } & 130 & 1 & $\mathrm{G}$ & 89 & 1059 & 1 \\
\hline & & & G & 2 & 240 & 2 \\
\hline & & & G & 34 & 237 & 6 \\
\hline & & & W & $(+)$ & 69 & 3 \\
\hline & & & W & 14 & 187 & 7 \\
\hline \multirow[t]{4}{*}{ Hotrienol } & 110 & 4 & $\mathrm{G}$ & $(+)$ & 120 & 2 \\
\hline & & & G & 7 & 77 & 6 \\
\hline & & & W & 3 & 237 & 3. \\
\hline & & & W & 3 & 117 & 7 \\
\hline \multirow[t]{5}{*}{ Linalool } & 100 & 1 & G & 62 & 1506 & 1 \\
\hline & & & $\mathrm{G}$ & 11 & 77 & 2 \\
\hline & & & G & 167 & 823 & 6 \\
\hline & & & W & 6 & 375 & 3 \\
\hline & & & W & 8 & 93 & 7 \\
\hline \multirow[t]{5}{*}{ Nerol } & $400-500$ & 1 & $\mathrm{G}$ & 11 & 447 & 1 \\
\hline & & & G & $(+)$ & 43 & 2 \\
\hline & & & G & 15 & 57 & 6 \\
\hline & & & W & $(+)$ & 36 & 3 \\
\hline & & & W & 3 & 43 & 7 \\
\hline \multirow[t]{5}{*}{$\propto \cdot$ Terpineol } & $400-500$ & 1 & G & 19 & 145 & 1 \\
\hline & & & $\mathrm{G}$ & $(+)$ & 14 & 2 \\
\hline & & & $\mathrm{G}$ & 3 & 23 & 6 \\
\hline & & & W & 5 & 399 & 3 \\
\hline & & & W & 7 & 52 & 7 \\
\hline 3,7 - Dimethylocta - 1,5 - dien - & - & - & G & 125 & 1497 & 6 \\
\hline $3,7-$ diol & & & W & 24 & 1174 & 7 \\
\hline 3,7 - Dimethylocta - 1,7 - dien - 3,6 - diol & - & - & G & 18 & 228 & 6 \\
\hline \multirow[t]{2}{*}{ Nerol oxide } & 100 & 4 & W & $(+)$ & 86 & 3 \\
\hline & & & W & 1 & 17 & 7 \\
\hline Rose oxides & - & - & W & $(+)$ & 19 & 3 \\
\hline & & & W & 2 & 258 & 3 \\
\hline & & & W & 5 & 21 & 7 \\
\hline \multirow[t]{4}{*}{ trans - Furan linalool oxide } & $>6000$ & 1 & $\mathrm{G}$ & 21 & 400 & 1 \\
\hline & & & G & $(+)$ & 15 & 2 \\
\hline & & & W & $(+)$ & 156 & 3 \\
\hline & & & $\mathrm{W}$ & 2 & 9 & 7 \\
\hline \multirow[t]{5}{*}{ cis - Pyran linalool oxide } & $3000-5000$ & 1 & $\mathrm{G}$ & 10 & 232 & 1 \\
\hline & & & $\mathrm{G}$ & 3 & 73 & 2 \\
\hline & & & $\mathrm{G}$ & 20 & 66 & 6 \\
\hline & & & W & $(+)$ & 74 & 3 \\
\hline & & & W & 1 & 7 & 7 \\
\hline \multirow[t]{4}{*}{ trans - Pyran linalool oxide } & $3000-5000$ & 1 & G & 20 & 349 & 1 \\
\hline & & & $\mathrm{G}$ & 5 & 89 & 2 \\
\hline & & & G & 67 & 271 & 6 \\
\hline & & & $\mathrm{W}$ & 16 & 58 & 7 \\
\hline $2,6,6$ - Trimethyl - 2 - vinyl - tetrahydropyran & - & - & W & 3 & 64 & 5 \\
\hline p - Cymene & - & - & W & 5 & 35 & 5 \\
\hline Limonene & - & - & W & 3 & 30 & 5 \\
\hline Myrcene & - & - & G & $(+)$ & 9 & 2 \\
\hline Y Terpinene & - & - & W & 6 & 35 & 5 \\
\hline
\end{tabular}

* The concentration ranges represent the sum of different cultivars analysed.

$(+)=$ Traces.

1. Ribéreau-Gayon, Boidron \& Terrier, 1975 (Muscat d'Alexandrie, Muscat blanc, Saint Vallier, Italia and Muscat Hambourg).

2. Schreier, Drawert \& Junker, 1976 a (Ruländer, Gewürztraminer, Scheurebe and Weisser Riesling).

3. Schreier, Drawert \& Junker, 1977 (Müller Thurgau, Weisser Riesling, Morio Muscat, Gewürztraminer, Ruländer and Scheurebe).

4. Simpson, 1979.

5. Noble, Flath \& Forrey, 1980 (Weisser Riesling).

6. Di Stefano, 1981 (A series of white Muscat grapes from Piemonte).

7. Versini, Inama \& Sartori, 1981 (Weisser Riesling).

amongst others included linalool presented a threshold value of $91 \mu \mathrm{g} / l$ (Ribéreau-Gayon et al., 1975).

Terpene compounds were also found in minor quantities in some non-muscat cultivars (Stevens, Bomben \& McFadden, 1967; Prillinger \& Madner, 1970). Bayonove
\& Cordonnier (1971) found linalool, $\propto$-terpineol, citral, citronellol, nerol and geraniol to occur in 10 to 100 times larger concentrations in muscat than in the non-muscat grape cultivars, Auxerrois, Weisser Riesling and Chasselas blanc but in approximately similar relative 
ratios. The authors also found that the addition of these terpene compounds to a neutral grape juice medium in the same ratios in which they had been found in muscat cultivars presented a character which corresponded with muscat aroma, but lacked balance. Consequently, the terpene compounds mentioned above do contribute to muscat aroma, but do not represent the complete aroma spectrum.

Terpene compounds were also identified in grape leaves. Wildenradt et el. (1975) reported that pentane extracts of Chenin blanc leaves contained terpenes and their derivatives as prominent compounds apart from the grassy $\mathrm{C}_{6}$ - compounds. Myrcene, linalool, $\propto$-terpineol, iso-pulegone, citral, geraniol, nerol and $\propto$ - and ß-ionone were identified. Augustyn \& Rapp (1982) failed to find measurable concentrations of terpenes in the berries of Chenin blanc, and the question arises whether and which biochemical processes are involved in the possible translocation of terpene compounds from the leaves to the grapes.

Identification of and differentiation between cultivars, using terpenes: Generally, it is difficult to differentiate analytically between grape cultivars. An exception in this regard is muscat and aroma related cultivars, since cultivar-typical grape aroma components, such as terpene compounds, are quite suitable for the analytical differentiation between some cultivars (Schreier, 1979). Terpene composition, as well as their concentrations differ between cultivars and are responsible for differences in aroma. By employing mathematical techniques, considerable research has been done in order to identify cultivars and to distinguish between them on the basis of their terpene composition and concentrations. These analyses were useful in establishing which compounds were cultivar-typical, such as terpenes, as well as in determining their effect on the quality of grapes and wine (Wagner, Dirninger \& Fuchs, 1974; Rapp \& Hastrich, 1976; Schreier, Drawert \& Junker, 1976 a; Rapp \& Hastrich, 1978 b).

Terrier et al. (1972 b) demonstrated cultivar-typical distribution patterns of geraniol, nerol, $\propto$-terpineol and the linalool oxides in different white $V$. vinifera cultivars. Schreier et al. (1976 c) and Drawert \& Schreier (1978) succeeded in distinguishing mathematically between the cultivars Ruländer, Morio Muscat, Gewürztraminer, Scheurebe, Weisser Riesling and Müller Thurgau using the concentrations of the terpene compounds linalool, hotrienol, geraniol, nerol, $\propto$-terpineol, nerol oxide, the rose oxides and the linalool oxides of grapes as well as wines. In this case, the rose oxides and nerol oxide emerged as the aroma components with the most significant discriminating abilities. Rapp, Hastrich \& Engel (1977), Rapp \& Hastrich (1978 a) and Rapp et al. (1978) undertook detailed investigations into the aroma ("fingerprint") patterns of different cultivars. By employing the concentrations of certain terpene compounds the authors could differentiate between the cultivars Sylvaner, Weisser Riesling and Morio Muscat and the cross B 6 - 18 irrespective of grape maturity, vintage year and origin. More subtle differentiations ('fine pattern"') were also possible between Weisser Riesling grapes cultivated in different wine areas.

The effect of grape maturity on terpene concentrations: Several studies were undertaken to determine the effect of grape maturity on terpene concentrations in muscat and aroma related cultivars (Hardy, 1970; Terrier et al. 1972 b; Cordonnier, 1974; Rapp et al. 1978). Bayonove \& Cordonnier $(1970 \mathrm{a}, \mathrm{b})$ established that in the case of several muscat cultivars linalool is absent in the unripe grapes, appears at the beginning of ripening at the same time as the muscat aroma, increases in concentration until maturity is reached and then decreases in concentration with over-ripeness. Bayonove \& Cordonnier (1971) observed increases in concentrations, similar to that of linalool, of other terpenes until maturity is reached. Ripe grapes contained about six times more linalool, five times more $\propto$-terpineol, four times more nerol and 1,4 times more geraniol than unripe grapes, while citral and citronellol occurred in nearly the same concentrations in the unripe and ripe grapes. Versini et al. (1981) determined terpenes in Weisser Riesling grapes during the final ripening period (about one month) and observed increases as well as decreases in different terpene concentrations. These studies clearly indicated that the maximum aroma can be attained before all the sugar has been accumulated.

In contrast to the above-mentioned findings, preliminary investigations (A. Rapp, O. P. H. Augustyn \& L. Engel, 1980; personal communication) indicated decreases in the concentrations of certain terpenes of some muscat and aroma related cultivars in South Africa with an increase in grape maturity. Reasons for these contradicting tendencies must still be found, but may possibly be ascribed to, amongst others, the warm South African climatic conditions.

Wagner et al. (1977), Cordonnier \& Bayonove (1978) and Simpson (1979 b) stressed the importance of harvesting grapes at the correct maturity. In order to exploit the aromatic potential of muscat and aroma related grapes, they should be harvested before maximum sugar accumulation, at least before over-ripeness, but not too early in order to prevent the detrimental effect of components derived from unripe grapes on wine quality. The optimum maturity of grapes in terms of the optimum terpene composition must still be determined.

The effect of certain wine-making techniques on terpene concentrations and wine quality: In general, there is proportionately higher concentrations of nerol in muscat grapes with small berries compared to those with larger berries, such as Muscat d'Alexandrie. Geraniol and linalool represent approximately $75 \%$ to $80 \%$ of the total terpene content of grapes and wine, and the largest amounts were found in the case of Muscat d'Alexandrie (Cordonnier \& Bayonove, 1978). The volatile components of the berry are mainly found in the skin and the solid parts of the cells. In the case of terpene compounds, Bayonove, Cordonnier \& Ratier (1974), Cordonnier \& Bayonove (1978) and Cordonnier \& Bayonove (1981) indicated that in Muscat d'Alexandrie grapes, $94 \%$ of geraniol and $96 \%$ of nerol are located in the skin, whereas linalool is almost equally distributed between the juice $(50 \%)$ on the one hand and the skin $(26 \%)$ and cellular debris $(24 \%)$ on the other. Versini et al. (1981) found similar trends for geraniol, nerol and citronellol in the case of Weisser Riesling grapes, namely the occurrence of high concentrations in the skins. Linalool also occurred in greater concentrations in the skins, namely $60 \%$. The linalool oxides appeared in evenly distributed concentrations between the skins 
and the juice plus cellular debris, whereas hotrienol, $\propto$-terpineol and 3,7 - dimethylocta - 1,5 - dien - 3,7 diol mainly occurred in the juice plus cellular debris. Bayonove et al. (1976) found the distribution of hotrienol in Muscat blanc to be $14,5 \%$ in the cmllular debris, $30 \%$ in the skin and $55 \%$ in the juice. In other words, the aromatic profile of the skin differs from that of the juice, and skin-contact may affect wine quality by affecting the intensity as well as the quality of the aroma. The quick removal of juice from the skins in the conventional technique of white wine-making, which is designed to limit phenolic compounds as far as possible, may lead to ignoring of the fact that important aroma components are located in the skin (Cordonnier \& Bayonove, 1981).

Different pressing techniques may affect the terpene composition of juice and quality of wines significantly. Generally speaking, pressed juice contains terpene alcohols in two to four times higher concentrations than the corresponding free-run juice. Nerol and geraniol especially show distinctly higher concentrations in press juice than in free-run juice (Cordonnier \& Bayonove, 1981). Kinzer \& Schreier (1980) compared the effect of different pressing systems, namely the screw press, the cylindrical Willmess press and a combination of the Willmess press and a chemical pressing-aid material on the composition of volatile constituents in unfermented musts and wines. The free-run juice and the press fractions were compared in each case. It was found that, in the case of Morio Muscat musts and wines, concentrations of compounds of cultivar origin, such as terpenes, increased with an increase in pressure. Sensory evaluation of the wines were not performed.

Versini et al. (1981) systematically compared terpene concentrations of Weisser Riesling grapes and the corresponding musts and wines. Pressing of the grapes increased terpene concentrations markedly from the grapes to the musts (7-8 times for geraniol, nerol and citronellol), as well as in the wines (5-10 times for linalool, nerol, hotrienol, $\propto$-terpineol and the furan linalool oxides). Furthermore, the authors investigated the effect of maceration, which included different contact times, a $\mathrm{CO}_{2}$ atmosphere, the use of pectolytic enzymes and heating of the pressed juice on terpene concentrations. Although individual terpenes behaved differently, generally increases in terpene concentrations were observed. The evaluation of the effects of these treatments on wine quality, as well as statistical correlations of terpenes with wine quality were still in progress at the time of publication.

Heat-treatment or pasteurisation of grape juice may have a highly significant effect on the concentrations of specific terpenes in the juice and the wines produced from it. Bound terpenes in the juice, such as linalool, hotrienol and $\propto$-terpineol may be released, and this may result in an increase in the concentrations of these terpenes. Hotrienol mainly occurs in its bound form in the juice of the berry and only in small quantities in the skin itself (Usseglio-Tomasset \& Di Stefano, 1979). Usseglio-Tomasset \& Di Stefano (1979) and UsseglioTomasset \& Di Stefano (1980) in fact demonstrated gas chromatographically that the concentration of linalool doubled, that of $\propto$-terpineol increased eightfold and that of hotrienol hundredfold after steam distillation of must for one hour at $70^{\circ} \mathrm{C}$. The concentrations of nerol and geraniol were also increased. Bound terpenes are discussed in more depth in the next section. UsseglioTomasset (1981) investigated the effect of heattreatment on terpene concentrations of Muscat blanc juice and wines, and found decreases in linalool and increases in hotrienol, $\propto$-terpineol, nerol and geraniol concentrations. Although nuances of the wine-aromas were modified, the overall quality and aroma intensities were improved.

Ethanol may play an important role in the extraction of terpenes from the grape particles (Cordonnier \& Bayonove, 1981). Even when present in low concentrations during maceration, ethanol may act as an extraction solvent. Strauss \& Williams (1983) found that during the distillation of Muscat d'Alexandrie wine the presence of ethanol caused the formation of linalyl, $\propto$-terpinyl, neryl and geranyl ethyl ethers.

Transformations of terpene compounds in grapes and wine: It is well-known that transformations of terpenes may take place during the storage of grapes and the production and maturation of wines. Muscat and aroma related wines may lose their cultivar characters to a large extent during maturation (Wenzel \& De Vries, 1968; Simpson, 1979 a). Vitispirane (Simpson, Strauss \& Williams, 1977) and 1,1,6 - trimethyl - 1,2 - dihydronaphthalene (responsible for the kerosene flavour, Simpson, 1978) which are of terpenic origin, were found to develop in Weisser Riesling wines during maturation and affect wine aroma and quality significantly.

Terpene compounds in grapes and wines are sensitive to acidic conditions and to increases in temperature and storage time. Under these conditions they are transformed to compounds which may be more or less aroma intensive and which may present a different character in wine (Terrier \& Boidron, 1972 a,b; Terrier et al., 1972 a,b; Whittaker, 1972). An example in this respect is the acid-catalysed rearrangement of nerol and linalool to a mutual carbo-cation which could further be stabilised to $\propto$-terpineol, terpinolene and limonene. RibéreauGayon et al. (1975) stated that linalool can easily be oxidised via an epoxide into four oxides, namely cis- and trans- furan linalool oxides and cis- and trans- pyran linalool oxides. Furthermore, geraniol is transformed into $\propto$-terpineol, and nerol, the isomer of geraniol, may react similarly. Bezzubov et al. (1980) and Batiashvili et al. (1980) discussed the oxidation of terpenes, such as linalool and geraniol in grapes and wines and found as a result losses in wine aroma. Castino \& Di Stefano (1981) investigated the effect of storage temperature on the characteristics of Asti Spumante wines and found significant decreases in terpene alcohol concentrations of the wines stored at $20^{\circ} \mathrm{C}$, compared to storage at $10^{\circ} \mathrm{C}$. It is clear that some of the most intense aromatic terpene compounds with low aroma threshold values may be transformed into terpenes with high aroma threshold values, and these re-arrangements may result in the loss of muscat and related aromas during storage of grapes and wine.

Williams et al. (1980 a) identified four new hydroxylated linalool derivatives in the chloroform extracts of Muscat d'Alexandrie grapes and suggested their possible formation from 6,7 - epoxydihydrolinalool by means of a series of enzyme-mediated transformations. Williams et al. (1980 b) demonstrated the non-enzymatic 
rearrangements of these four hydroxylated linalool derivatives at the $\mathrm{pH}$ of the grape juice $(3,2)$ to give several volatile terpenes. Heating Muscat d'Alexandrie grape juice for 15 minutes at $70^{\circ} \mathrm{C}$ resulted in an increase in the concentrations of cis- and trans-furan linalool oxides, nerol oxide, hotrienol and $\propto$-terpineol. Simultaneously seven new terpene compounds were identified as grape aroma components. Acid-catalysed hydrolysis of model solutions of the four hydroxylated linalool derivatives is illustrated in Figure 1.

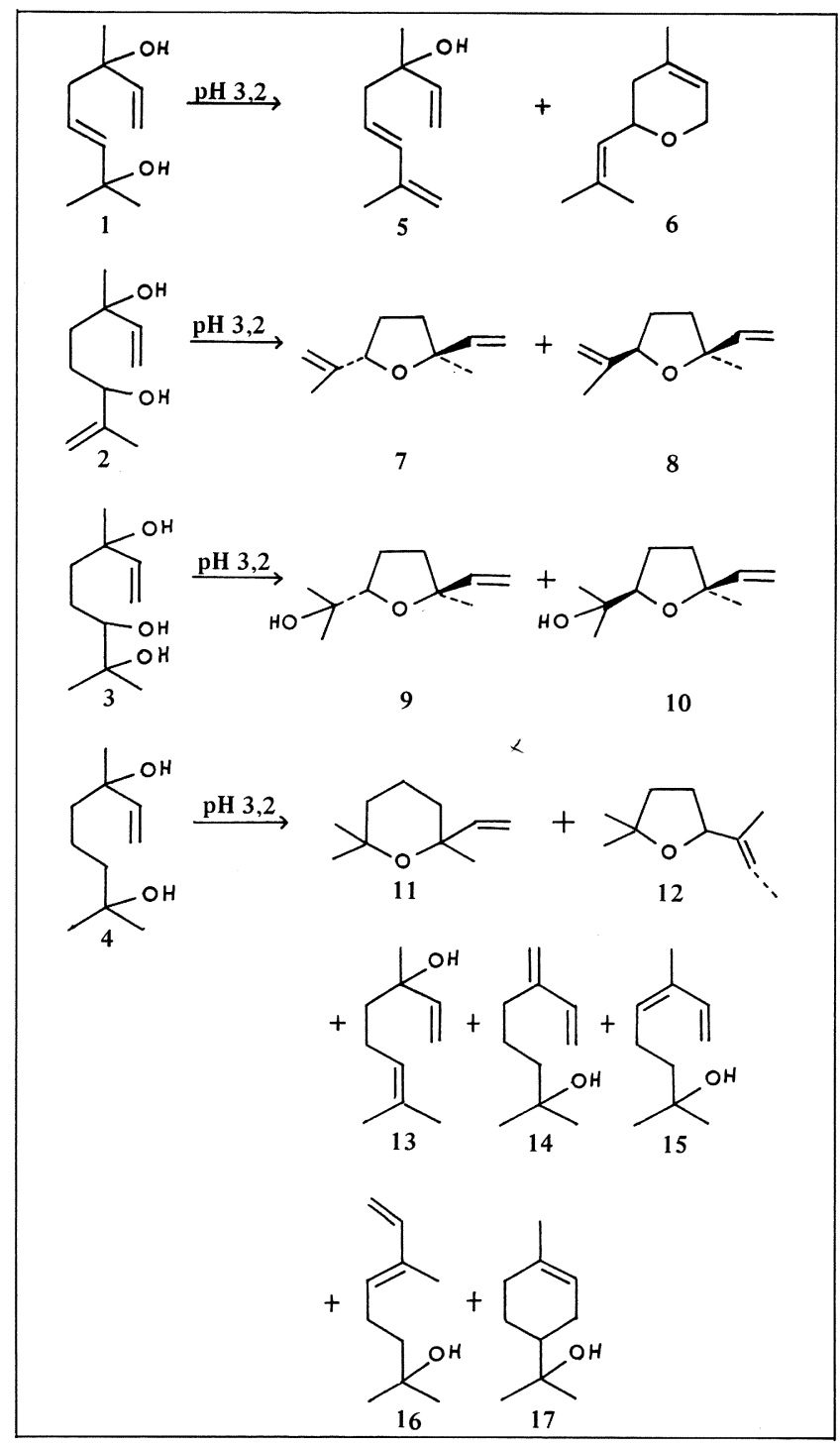

FIGURE 1

Acid hydrolysis products of grape polyols 1-4 (Williams, Strauss \& Wilson, $1980 \mathrm{~b}$ ).

1. 3,7 - Dimethylocta - 1,5 - dien - 3,7 - diol.

2. 3,7 - Dimethylocta - 1,7 - dien - 3,6 - diol.

3. 3,7 - Dimethyloct - 1 - en - 3,6,7 - triol.

4. 3,7 - Dimethyloct - 1 - en - 3,7 - diol.

5. Hotrienol.

6. Nerol oxide.

7. trans - Anhydrofuran linalool oxide.

8. cis - Anhydrofuran linalool oxide.

9. trans - Furan linalool oxide.

10. cis - Furan linalool oxide.

11. 2,6,6 - Trimethyl - 2 - vinyl - tetrahydropyran.

12. 2,2 - Dimethyl - 5 - (1 - methyl-propenyl) tetrahydrofuran.

13. Linalool.

14. Myrcenol.

15. cis - Ocimenol.

16. trans - Ocimenol.

17. $\propto$ - Terpineol.
It is clear that some terpene compounds which are almost odourless, may be rearranged during acidcatalysed hydrolysis to yield increases in the concentrations of existing terpenes as well as the formation of new terpene compounds with quite low aroma threshold values. The formation of large amounts of certain terpenes from limited amounts of linalool derivatives could however not be explained. Cordonnier \& Bayonove (1974) suggested that terpenes occur in bound forms in muscat grapes, namely as carbohydrate derivatives. However, no terpene glucosides were isolated. They believed that under certain conditions during maturation of grapes and fermentation, these bound terpenes release additional quantities of volatile terpenes which may contribute significantly to the muscat aroma. For example, a monoterpene fraction of Muscat d'Alexandrie grapes may release linalool by means of enzyme-mediated hydrolysis (Cordonnier \& Bayonove, 1974).

Usseglio-Tomasset \& Di Stefano (1979) indicated that linalool, $\propto$-terpineol and hotrienol mainly occur in their bound forms in grape musts. During fermentation a modest liberation of terpenes, especially $\propto$-terpineol, takes place, and increases in their concentrations in wines are consequently observed. Usseglio-Tomasset \& Di Stefano (1980) further discussed the existence of bound precursor terpenes and demonstrated the transformations of individual pure commercial terpenes to other terpenes in an aqueous $10 \%$ alcohol solution, subjected to heat-treatment at wine $\mathrm{pH}$. It is clear that heattreatment of grape juice gives rise to changes in the terpene composition, and $\propto$-terpineol and hotrienol are some of the major products. Di Stefano (1981) determined terpene and terpenoid concentrations in white Muscat grapes and mentioned that two-thirds of the linalool content often occur in the combined form. He also demonstrated reaction mechanisms for the production of linalool, $\propto$-terpineol, nerol and geraniol from a linalool precursor.

In the same context, Williams, Strauss \& Wilson (1981) investigated the presence of non-volatile, bound (conjugated) precursor terpenes and volatile free terpenes in Muscat d'Alexandrie grapes. Factors such as temperature and acid hydrolysis induced the rearrangement of bound terpenes into free terpenes. Grape juice was extracted with pentane seven times. These pentane extracts contained the free terpenes. The pentane-stripped juice was further extracted with Freon 11 , and this extract contained the more polar, polyhydroxylated monoterpenes which are also viewed as free terpenes; The pentane-freon-stripped juice contained the remaining highly water-soluble bound terpenes and this juice, when heated to $70^{\circ} \mathrm{C}$ at low $\mathrm{pH}$, induced the transformation of bound terpenes into free terpenes. Some of the major products formed at $\mathrm{pH} \mathrm{3,0}$ were hotrienol, linalool, $\propto$-terpineol and the furan linalool oxides. When the $\mathrm{pH}$ of the juice was adjusted to 1,0 and the juice heated to $70^{\circ} \mathrm{C}$, myrcenol and cis- and trans-ocimenol were major products. Furthermore, cisand trans - 1,8 - terpin, which had not yet been identified in grapes and wine, also emerged as prominent terpenes. The mechanisms by which these rearrangements occurred were then not clear. The authors speculated that the different oxidation levels of the terpene compounds possibly played an important role in this 
regard. In view of the presence of bound terpenes and their incomplete rearrangements into free terpenes during different wine-making procedures as well as during extraction procedures of grape juice at normal juice $\mathrm{pH}$, quantitative results of terpene concentrations in grape juice and wines should be interpreted with caution (Williams et al., 1981).

It became evident from the above-mentioned research that concentrations of terpene compounds and consequently the aroma of wine, would definitely be affected by certain wine-making techniques such as heattreatment of grapes and must.

Williams et al. (1982 a) confirmed the occurrence of bound terpenes as glucosidic derivatives and isolated them from grape juice and wines by means of $\mathrm{C}_{18^{-}}$ bonded reversed-phase liquid chromatography. This type of chromatography allowed separation of glucosidic precursors of monoterpenes at different oxidation levels. Simultaneously, precursors of the important norisoprenoid grape and wine aroma components, namely vitispirane, 1,1,6 - trimethyl - 1,2 - dihydronaphthalene and damascenone were identified. When the grape juice was subjected to drastic conditions, namely $\mathrm{pH} \mathrm{1,0} \mathrm{and}$ $70^{\circ} \mathrm{C}$, the formation of various terpenes, which have not yet been identified in grapes and wine, was induced. They were amongst others 1,4 - cineole, 1,8 cineole, $\propto$-terpinene, cis- and trans-ocimene, terpinolene, terpinen-1-ol and trans- 2,6-dimethylocta -3,7 - dien -2,6 - diol. Di Stefano (1982) isolated a linalool precursor from white Muscat of Piemonte which, by acid hydrolysis, mainly produced linalool and arabinose.

Williams et al. (1982 b) identified the glycosidic precursors of the geraniol oxidation state monoterpenes of both Muscat d'Alexandrie and Weisser Riesling grapes and wines and thus clarified the origin of the free terpenes involved. They were found to be a complex mixture of disaccharides namely $\beta$ - rutinosides and 6-0- $\propto$-L-arabinofuranosyl - $\beta$-D-glucopyranosides of several monoterpene alcohols. These findings were confirmed by hydrolysis studies of synthetic neryl, geranyl and linalyl $\beta$-D- glucopyranosides (Williams et al., 1982 c).

Boidron (1978) investigated the effect of Botrytis cinerea infection on the decomposition of terpenes in grape juice and found decreases in the concentrations of linalool, $\propto$-terpineol, geraniol, nerol, hotrienol and terpene oxidation products, as well as an eventual disappearance of the majority of the terpene compounds and the distinct muscat aroma with an increase in infection. Shimizu, Uehara \& Watanabe (1982) demonstrated the transformations of some monoterpenes to other terpenes when added to artificially botrytized grape must. The concentration of a mixture of cis- and trans-furan linalool oxides remained unchanged, whereas the concentrations of linalool, terpinen - 4 -ol and $\propto$-terpineol decreased markedly. When only linalool was added to the must, 12 terpenes were produced. They were $\beta$-pinene, cis- and trans-furan linalool oxides, p-menthane-1-en-3-one, $\propto$-terpineol, cis- and trans-pyran linalool oxides, geraniol, p-menthane-1,8-dien-9-ol and three unidentified monoterpenes. When only terpinen - 4-ol was added to the must, only one terpene, namely geranial, was produced. Botrytis cinerea did not produce terpene compounds in grape must lacking terpenes.
Yeasts are able to produce terpenes. Drawert \& Barton (1978) demonstrated the formation of citronellol, linalool and geraniol by the yeast Kluyveromyces lactis in aerobic submerged culture. By changing the culture conditions, the yield of monoterpenes such as citronellol was affected. Fagan, Kepner \& Webb (1981) reported the production of linalool, cis- and trans-nerolidol and trans, transfarnesol by the wine yeast Saccharomyces fermentati. This was carried out by the yeast growing for 10 weeks as a film on the surface of a simulated fino sherry, which contained ethanol as the only volatile carbon containing compound.

Terpene transformations which involve the actions of enzymes has been discussed by Croteau (1975) who concluded that, in spite of limited knowledge in this respect, several highly specific enzymes are involved in terpene metabolism and transformations. The enzyme trans- cis-isomerase seems to be a key enzyme in terpene metabolism, since it functions at the conditions where geranyl pyrophosphate is transformed into cyclic monoterpenes, while further condensation to farnesyl pyrophosphate is prevented. Another key reaction in the biosynthesis of monoterpenes appears to be the enzymatic dehydration of $\propto$-terpineol to terpinolene and limonene. $\propto$-Terpineol is mainly dehydrated to terpinolene in the case of extracts of carrot roots and to limonene in the case of peppermint leaves. During the crushing of grapes, intense enzymatic activities occur. The enzymatic liberation of terpenes from sugar molecules by specific enzymes, such as $\beta$-glucosidase may possibly occur, which may affect wine aroma significantly (Cordonnier \& Bayonove, 1981).

Due to the relative instability of terpene compounds, transformations of terpenes may also occur as a result of vigorous and lengthy extraction procedures (Williams et al., 1980 b). As already mentioned, factors such as an increase in temperature and acid conditions result in marked increases in the concentrations of some existing terpenes as well as the formation of new terpene compounds. In other words, terpenes may also be produced as artefacts which consequently do not represent the original aroma profile of grapes and wine (UsseglioTomasset \& Di Stefano, 1979; Williams et al., 1980 b). More accurate and mild isolation techniques, such as headspace methods, which involve the sampling and concentration of aroma components in the headspace above wines, appear to be the most acceptable. These techniques should produce an aroma profile which is more representative of those volatiles of grape juice and wine which actually enter the nose when the product is being smelt (Williams, 1982). Rapp \& Knipser (1980) described a method for the enrichment of headspace components of wine in which the mild conditions involved prevent the formation of artefacts as far as practically possible.

Research indicates clearly that terpene compounds are responsible for some of the most important and prominent aromas in grapes and wines. Technological development of analytical instruments make it possible to gain deeper insight into the nature of terpenes. Factors such as cultivar, climatic conditions, grape maturity, $\mathrm{pH}$, enzymes, lengthy storage times, extraction procedures and wine-making procedures such as maceration, heat-treatment and pressing may have a 
significant effect on the volatile terpene content of grapes and wines and on wine quality. By improving quantification of terpenes, and utilisation of available knowledge, the adaptability of different cultivars to different climatic regions may be utilised better, and high quality wines with more specific aroma styles may be produced.

\section{LITERATURE CITED}

AUGUSTYN, O. P. H. \& RAPP, A., 1982. Aroma components of Vitis vinifera L. cv. Chenin blanc grapes and their changes during maturation. S. Afr. J. Enol. Vitic. 3, 47-51.

AUSTERWEIL, G., 1946. Quelques observations sur les parfums des vins. Ind. Parfum. 1, 195-199.

BATIASHVILI, T.A., BEZZUBOV, A. A., CHICHASVILI, N. D. \& RODOPULO, A. K., 1980. Changes in the essential oil compositions of grapes during their treatment (for wine). Prikl. Biokhim. Mikrobiol. 16, 609-611. (Chem. Abstr. 93 (13), 236847c, 1980).

BAYONOVE, C. \& CORDONNIER, R., 1970 a. Recherches sur l'arôme du muscat. I. Evolution des constituants volatils au cours de la maturation du Muscat d'Alexandrie. Ann. Technol. Agric. 19, 79-93.

BAYONOVE, C. \& CORDONNIER, R., 1970 b. Recherches sur l'arôme du muscat. II. Profils aromatiques de cépages muscat et non muscat. Importance du linalol chez les muscats. Ann. Technol. Agric. 19, 95-105.

BAYONOVE, C. \& CORDONNIER, R., 1971. Recherches sur l'arôme du muscat. III. Étude de la fraction terpénique. Ann. Technol. Agric. 20, 247-355.

BAYONOVE, C., CORDONNIER, R. \& RATIER, R., 1974. Localisation de l'arôme dans la baie de raisin : varietés Muscat d'Alexandrie et Cabernet Sauvignon. C. R. Séances Acad. Agric. Fr. 60, 1321-1328.

BAYONOVE, C., RICHARD, H. \& CORDONNIER, R., 1976. Isolement et identification du diméthyl -3.7 octatriène - 1.5.7 ol -3 ou trans hotrienol, constituant à odeur de Tilleul de l'huile essentielle de Muscat de Frontignan. C. R. Acad. Sc. Paris, Sér. C. 283, 549-551.

BEZZUBOV, A. A., RODOPUlO, A. K., EGOROV, I. A. \& NECHAEV, L. N., 1980. Aroma-forming substances of grape hybrid varieties and wines produced from them. Prikl. Biokhim. Mikrobiol. 16, 120-126 (Chem. Abstr. 92 (12), 196305v, 1980).

BOIDRON, J. N., 1978. Relation entre les substances terpéniques et la qualité du raisin (Rôle du Botrytis cinerea). Ann. Technol. Agric. 27, 141-145.

CASTINO, M. \& DI STEFANO, R., 1981. Effetti della temperatura di conservazione sulle caratteristiche dell'Asti Spumante. Riv. Vitic. Enol. 34, 106-119.

CORDONNIER, R., 1956. Recherches sur l'aromatisation et le parfum de vins doux naturels et des vins de liqueur. Ann. Inst. Natl. Recherches Agron. Sér. E. Ann. Technol. Agric. 5, 75-110.

CORDONNIER, R., 1974. L'arôme des vins. Progr. Agric. Vitic. 91, 320-329.

CORDONNIER, R. \& BAYONOVE, C., 1974. Mise en évidence dans la baie de raisin, variété Muscat d'Alexandrie, de monoterpénes liés révélables par une ou plusieurs enzymes du fruit. C. R. Acad. Sc. Paris, Sér. D. 278, 3387-3390.

CORDONNIER, R. \& BAYONOVE, C., 1978. Les composantes variétales et prefermentaires de l'arôme des vins. Extrait de Parfum Cosmétiques arômes. 24, 67-77.

CORDONNIER, R. \& BAYONOVE, C., 1981. Étude de la phase prefermentaire de la vinification: Extraction et formation de certains composes de l'arôme; cas des terpenols, des aldehydes et des alcools en $\mathrm{C}_{6}$. Connaiss. Vigne Vin. 15, 269-286.

CROTEAU, R., 1975. Biosynthesis of monoterpenes and sesquiterpenes. Geruch- und Geschmackstoffe. Verlag Hans Carl Nürnberg. 153-166.

DEVON, T. K. \& SCOTT, A. I., 1972. Handbook of naturally occurring compounds. Volume II. Terpenes. Academic Press, New York.

DI STEFANO, R., 1981. Terpene compounds of white Muscat from Piemonte. Vini. Ital. 23, 29-43.
DI STEFANO, R., 1982. Presenza di precursori del linalolo nel Moscato bianco del Piemonte. Vignivini IX, 45-47.

DRAWERT, F. \& BARTON, H., 1978. Biosynthesis of flavor compounds by micro-organisms. 3. Production of monoterpenes by the yeast Kluyveromyces lactis. J. Agric. Food Chem. 26, 765-766.

DRAWERT, F. \& SCHREIER, P., 1978. Caractérisation des raisins et des vins à l'aide de certains constituants remarquables. Ann. Technol. Agric. 27, 367-375.

FAGAN, G. L., KEPNER, R. E. \& WEBB, A. D., 1981. Production linalool, cis- and trans-nerolidol, and trans, trans- farnesol by Saccharomyces fermentati growing as a film on simulated wine. Vitis 20, 36-42.

HARDY, P. J., 1970. Changes in volatiles of muscat grapes during ripening. Phytochemistry 9, 709-715.

KINZER, G. \& SCHREIER, P., 1980. Influence of different pressing systems on the composition of volatile constituents in unfermented grape musts and wines. Am. J. Enol. Vitic. 31, 7-13.

KLOUWEN, M. H. \& TER HEIDE, R., 1962. Studies on terpenes. I. A systematic analysis of monoterpene hydrocarbons by gasliquid chromatography. J. Chrom. 7, 297-310.

MEILGAARD, M. C., 1975. Flavour chemistry of beer: Part II: Flavour and threshold of 239 aroma volatiles. Tech. Q. Master Brew. Assoc. Am. 12, 151-168.

NOBLE, A. C., FLATH, R. A. \& FORREY, R. R., 1980. Wine headspace analysis. Reproducibility and application to varietal classification. J. Agric. Food Chem. 28, 346-353.

PINDER, A. R., 1960. The chemistry of the terpenes. Chapman \& Hall. LTD London.

PRILLINGER, F. \& MADNER, A., 1970. Die flüchtigen Inhaltsstoffe von Muskatmosten und-weinen. Mitt. Klosterneuburg. 20, 202-205.

RAPP, A. \& HASTRICH, H., 1976. Gaschromatographische Untersuchungen über die Aromastoffe von Weinbeeren. II. Möglichkeiten der Sortencharakterisierung. Vitis 15, 183-192.

RAPP, A., HASTRICH, H. \& ENGEL, L., 1977. Kapillarchromatographische Untersuchungen über die Aromastoffe von Wein und Weinbeeren. Möglichkeiten zur Sortencharakterisierung. Mitt. Klosterneuburg. 27, 74-82.

RAPP, A. \& HASTRICH, H., 1978 a. Gaschromatographische Untersuchungen über die Aromastoffe von Weinbeeren. III. Die Bedeutung des Standortes für die Aromastoffzusammensetzung der Rebsorte Riesling. Vitis 17, 288-298.

RAPP, A. \& HASTRICH, H., 1978 b. Application de la chromatographie en phase gazeuse à la caractérisation des variétés. Ann. Technol. Agric. 27, 423-426.

RAPP, A., HASTRICH, H., ENGEL, L. \& KNIPSER, W., 1978. "Flavor of foods and beverages". Possibilities of characterizing wine quality and vine varieties by means of capillary chromatography. Academic Press, N.Y., S.F. Lond. 391-417.

RAPP, A. \& KNIPSER, W., 1979. 3,7 - Dimethyl-okta-1,5-dien3,7-diol -eine neue terpenoide Verbindung des Trauben- und Weinaromas. Vitis 18, 229-233.

RAPP, A. \& KNIPSER, W., 1980. Eine neue Methode zur Anreicherung von Dampfkomponenten. Dargestelt am Beispiel des Weines. Chromatographia 13, 698-702.

RAPP, A., KNIPSER, W. \& ENGEL, L., 1980. Identifizierung von 3,7-Dimethyl-okta - 1,7 - dien - 3,6 - diol im Trauben- und Weinaroma von Muskatsorten. Vitis 19, 226-229.

RIBÉREAU-GAYON, P., BOIГRON, J. N. \& TERRIER, A., 1975 Aroma of Muscat grape varieties. J. Agric. Food Chem. 23, 1042-1047.

SCHREIER, P., 1979. Flavor composition of wines: a review. $C R C$ Crit. Rev. Food Sci. Nutr. 12, 59-111.

SCHREIER, P. \& DRAWERT, F., 1974 a. Gaschromatographisch massenspektrometrische Untersuchung flüchtiger Inhaltsstoffe des Weines. I. Unpolare Verbindungen des Weinaromas. $Z$. Lebensm. Unters.-Forsch. 154, 273-278.

SCHREIER, P. \& DRAWERT, F., 1974 b. Gaschromatographisch massenspektrometrische Untersuchung flüchtiger Inhaltsstoffe des Weines. V. Alkohole, Hydroxy-Ester, Lactone und andere polare Komponenten des Weinaromas. Chem. Mikrobiol. Technol. Lebensm. 3, 154-160.

SCHREIER, P., DRAWERT, F. \& JUNKER, A., 1974. Identifizierung von 3,7 - Dimethyl - 1,5,7 - octatrien-3-ol als flüchtige Komponente des Trauben- und Weinaromas. Z. Lebensm. Unters.-Forsch. 155, 98-99. 
SCHREIER, P., DRAWERT, F. \& JUNKER, A., 1976 a. Gaschromatographisch - massenspektrometrische Differenzierung der Traubenaromastoffe verschiedener Rebsorten von Vitis vinifera. Chem. Mikrobiol. Technol. Lebensm. 4, 154-157.

SCHREIER, P., DRAWERT, F. \& JUNKER, A., 1976 b. Identification of volatile constituents from grapes. J. Agric. Food Chem. 24, 331-336.

SCHREIER, P., DRAWERT, F., JUNKER, A. \& REINER, L., 1976 c. Anwendung der multiplen Diskriminanzanalyse zur Differenzierung von Rebsorten an Hand der quantitativen Verteilung flüchtiger Weininhaltsstoffe. Mitt. Klosterneuberg. 26, 225-234.

SCHREIER, P., DRAWERT, F. \& JUNKER, A., 1977. Gaschromatographische Bestimmung der Inhaltsstoffe von Gärungsgetränken. X. Quantitative Bestimmung von Weinaromastoffen in myg/l-Bereich. Chem. Mikrobiol. Technol. Lebensm. 5, 45-52.

SHIMIZU, J., UEHARA, M. \& WATANABE, M., 1982. Transformation of terpenoids in grape must by Botrytis cinerea. Agric. Biol. Chem. 46, 1339-1344.

SIMPSON, R. F., 1978. 1,1,6-Trimethyl-1,2-dihydronaphthalene: an important contributor to the bottle aged bouquet of wine. Chem. Ind., 37.

SIMPSON, R. F., 1979 a. Aroma composition of bottle aged white wine. Vitis 18, 148-154.

SIMPSON, R. F., 1979 b. Some important aroma components of white wine. Food Technol. Aust. 31, 516-522.

SIMPSON, R. F., STRAUSS, C. R. \& WILLIAMS, P. J., 1977. Vitispirane: a $C_{13}$ spiro-ether in the aroma volatiles of grape juice, wines and distilled grape spirits. Chem. Ind., 663-664.

STEVENS, K. L., BOMBEN, J., LEE, A. \& McFADDEN, W. H., 1966. Volatiles from grapes. Muscat of Alexandria. J. Agric. Food Chem. 14, 249-252.

STEVENS, K. L., BOMBEN, J. \& McFADDEN, W. H., 1967. Volatiles from grapes. Vitis vinifera (Linn.) cultivar Grenache. J. Agric. Food Chem. 15, 378-380.

STRAUSS, C. R. \& WILLIAMS, P. J., 1983. The effect of distillation on grape flavour components, Flavour of Distilled Beverages Symp. 1-4th June. Univ. of Stirling, Scotland, U.K.

TER HEIDE, R., 1968. Studies on terpenes. II. Characterization of monoterpene esters by gas and thin-layer chromatography. Z. Anal. Chem. 236, 215-227.

TER HEIDE, R., 1976. Studies on terpenes. III. Gas chromatography of acyclic monoterpene alcohols. J. Chrom. 129, 143-154.

TERRIER, A. \& BOIDRON, J. N., 1972 a. Identification des derives terpéniques dans les raisins de certaines varietés de Vitis vinifera. I. Techniques expérimentales. Connaiss. Vigne Vin. 1, 69-85.

TERRIER, A. \& BOIDRON, J. N., 1972 b. Identification des derives terpéniques dans les raisins de certaines varietés de Vitis vinifera. II. Resultats. Connaiss. Vigne Vin. 2, 147-160.

TERRIER, A., BOIDRON, J. N. \& RIBÉREAU-GAYON, P., 1972 a. L'identification des composés terpéniques dans les raisins de Vitis vinifera. C.R. Acad. Sc. Paris, Sér.D. 275, 495-497.

TERRIER, A., BOIDRON, J. N. \& RIBÉREAU-GAYON, P., 1972 b. Teneurs en composés terpéniques des raisins de Vitis vinifera. C.R. Acad. Sc. Paris, Sér. D. 275, 941-944.

USSEGLIO-TOMASSET, L., 1966. L'aroma di moscato nelle uve e nei vini. Industr. Agrar. 4, 216-244.

USSEGLIO-TOMASSET, L., 1969. I costituenti aromatici delle uve. Riv. Vitic. Enol. 22, 223.

USSEGLIO-TOMASSET, L., 1981. Les substances aromatiques du vin et la possibilité de les augmenter par de traitements thermiques. Int. Oenol. Symp., (Pap.), 6th, 353-361.

USSEGLIO-TOMASSET, L., ASTEGIANO, V. \& MATTA, M., 1966. Il linalolo composto responsabile dell'aroma delle uve e dei vini aromatici. Industr. Agrar. 4, 583-584.

USSEGLIO-TOMASSET, L. \& DI STEFANO, R., 1979. Osservazioni sui costituenti terpenici delle uve e dei vini aromatici. Vignevini 6, X, 33-38.
USSEGLIO-TOMASSET, L. \& DI STEFANO, R., 1980. Profilo aromatico del Moscato bianco del Piemonte. Riv. Vitic. Enol. $33,58-68$.

VAN STRATEN, S., DE BEAUVESER, J. C. \& VISSCHER, C. A. 1977. "Volatile Compounds in Food", Supplement 5 (1980, wine), 70.1-70.9 and Supplement 6 (1981, grape) 9.1-9.6 to the Fourth Edition. Central Institute for Nutrition and Food Research TNO, Zeist, The Netherlands.

VERSINI, G., INAMA, S. \& SARTORI, G., 1981. A capillary column gaschromatographic research into the terpene constituents of "Riesling Renano" (Rhine Riesling) wine from Trentino Alto Adige: Their distribution within berries, their passage into must and their presence in the wine according to different wine-making procedures. Organoleptic considerations. Vini Ital. XXIII, 189-211.

WAGNER, R., DIRNINGER, N. \& FUCHS, V., 1974. Résultats préliminaires concernant l'étude génétique de substances odorantes décelées par chromatographie en phase gazeuse dans les fruits d'une descendance de Vitis vinifera L. Colloque C.N.R.S. "Facteurs et régulation de la maturité des fruits". 335-339.

WAGNER, R., DIRNINGER, N., FUCHS, V. \& BRONNER, A., 1977. Study of the intervarietal differences in the concentration of volatile constituents (linalool and geraniol) in the aroma of the grape. Interest of such analyses for the appreciation of the quality of the harvest. Int. Symp. Qual. Vintage. Cape Town, 137-142.

WEBB, A. D. \& KEPNER, R. E., 1957. Some volatile aroma constituents of Vitis vinifera var. Muscat of Alexandria. Food Res. 22, 384-395.

WEBB, A. D., KEPNER, R. E. \& MAGGIORA, L., 1966. Gas chromatographic comparison of volatile aroma materials extracted from eight different muscat-flavored varieties of Vitis vinifera. Am. J. Enol. Vitic. 17, 247-254.

WENZEL, K. W. O. \& DE VRIES, M. J., 1968. An investigation of muscat aroma. S. Afr. J. Agric. Sci. 11, 273-280.

WHITTAKER, D., 1972. The monoterpenes. Newman, A. A. ed. Chemistry of terpenes and terpenoids. Academic Press, London, 11-87.

WILDENRADT, H. L., CHRISTENSEN, E. N., STACKLER, B., CAPUTI, Jr., A., SLINKARD, K. \& SCUTT, K., 1975. Volatile constituents of grape leaves. I. Vitis vinifera variety 'Chenin blanc'. Am. J. Enol. Vitic. 26, 148-153.

WILLIAMS, A. A., 1982. Recent developments in the field of wine flavour research. J. Inst. Brew. 88, 43-53.

WILLIAMS, P. J., STRAUSS, C. R. \& WILSON, B., 1980 a. New linalool derivatives in Muscat of Alexandria grapes and wines. Phytochemistry 19, 1137-1139.

WILLIAMS, P. J., STRAUSS, C. R. \& WILSON, B., 1980 b. Hydroxylated linalool derivatives as precursors of volatile monoterpenes of muscat grapes. J. Agric. Food Chem. 28, 766-771.

WILLIAMS, P. J., STRAUSS, C. R. \& WILSON, B., 1981. Classification of the monoterpenoid composition of muscat grapes. Am. J. Enol. Vitic. 32, 230-235.

WILLIAMS, P. J., STRAUSS, C. R., WILSON, B. \& MASSYWESTROPP, R. A., 1982 a. Use of $C_{18}$ reversed-phase liquid chromatography for the isolation of monoterpene glycosides and nor-isoprenoid precursors from grape juice and wines. $J$. Chrom. 235, 471-480.

WILLIAMS, P. J., STRAUSS, C. R., WILSON, B. \& MASSYWESTROPP, R. A., 1982 b. Novel monoterpene disaccharide glycosides of Vitis vinifera grapes and wines. Phytochemistry 21, 2013-2020.

WILLIAMS, P. J., STRAUSS, C. R., WILSON, B. \& MASSYWESTROPP, R. A., 1982 c. Studies on the hydrolysis of Vitis vinifera monoterpene precursor compounds and model monoterpene $\beta$-D-glucosides rationalizing the monoterpene composition of grapes. J. Agric. Food Chem. 30, 1219-1223. 